\title{
Emerging issues for auditing in Islamic Financial Institutions: Empirical evidence from Malaysia
}

\author{
Nawal Kasim ${ }^{1}$, Zuraidah Mohd Sanusi ${ }^{2}$ \\ ${ }^{1}$ Accounting Research Institute, Faculty of Accountancy/ Universiti Teknologi MARA, Malaysia \\ ${ }^{2}$ Accounting Research Institute, Faculty of Accountancy/ Universiti Teknologi MARA, Malaysia
}

\begin{abstract}
The study examines the perspective of practitioners who are involved directly and/or indirectly with the process of shariah compliance/auditing from Islamic financial institutions (IFIs) in Malaysia on the issues of standards for shariah auditing, auditors qualifications and independence. The paper examines 77 selfdeveloped questionnaires applicable to the main issues focused by this study. The survey questionnaires are distributed by mail or delivered in person to 85 respondents in 21 Malaysian Islamic financial institutions. It is found that Malaysian IFIs are in need of properly guided shariah standards for shariah auditing practices. The scarce resourceful auditors with both shariah and accounting/auditing qualifications and the issue of self review threat to independence may affect the reputable image of Islamic financial institutions. The findings reinforce the importance of auditors' qualification and independence as currently there is no mandatory regulated professional shariah auditor code to be in tandem with drastic growth of the IFIs. The paper offers practical implication to regulators in providing a direction to revise the existing standards for shariah auditing practices and to formulate a mandatory professional governance structure for shariah auditors.
\end{abstract}

Keywords - Shariah audit, Shariah auditor, Islamic financial institutions, Malaysia

\section{INTRODUCTION}

Recent accounting scandals, where companies prepared fraudulent financial statements and auditors issued clean opinions on the fraudulent statements have eroded trust among participants in the financial markets. Barlup [1] have questioned whether increased regulation is the only solution to fraudulent financial reporting and auditing. Audit failures have led stakeholders to question on the importance of the audit process. Stakeholders wonder about the independence of auditors when management fraud occurs and questioned whether auditors improve the value of information available to outsiders.

People have started to re-evaluate the level of trust they put on audit to provide assurance for investment and financial information, and the trend of solely depending on audit as the best source of credibility for such information may have now become defunct [2]. The profession's problems started after high-flying Enron Corporation suddenly declared bankruptcy, followed by a few more giant conglomerates. Like it or not, auditors became regular features in front-page news stories and banner [3]. It has also been argued that the role of financial reporting and auditing should not be confined to the needs of investor decision-making, but should also be viewed in relation to the more general concerns of corporate governance [4].

These are comments which relate mainly to financial statements audits whereby the auditors only express their opinion on the accounts. The purpose of this type of audit is to determine whether the overall financial statements are stated in accordance with the specified criteria. Some stakeholders consider audited accounts guarantee their true and fair view, absence of fraud or even the going concern position of the entity. However, to them an audit is not an assurance of the future viability of an entity, nor it is an opinion on the economy, efficiency or effectiveness with which management has conducted its affairs [5].

Despite all these tragedies and criticisms, the conventional auditing system arising from a Western capitalistic philosophy and values is the only procedure and system available being globally adopted. Unfortunately, Islamic financial institutions (IFIs) which are set up with different objectives and world view have not much choice but to depend on the system for audit purposes. In view of their early stage, Islamic banks for instance, have no mandatory regulated guideline on auditing practices and accounting standards [6]. A standard setting body for IFIs called as The Accounting and Auditing Organization for Islamic Financial Institutions (AAOIFI) in their early process of setting accounting and auditing standards has adopted the 'ibaha' methodology which has come under criticisms by certain quarters. Shahul [7] for instance called for an extensive overhaul for Islamic accounting if it were to endure for a long time.

New regulations have been imposed to restore confidence in the corporate governance system and the oversight role in this system. The effect on the presence of a code of ethics for instance, appears to have an impact on the quality of auditors' judgments [8]. Hence, the introduction of Islamic laws into Islamic financial institutions has resulted in great changes; especially in the way the institutions do their business. This has also affected the audit of these institutions. Accordingly, the normal audit objective has been changed to agree with 
the Islamic law even though the normal conventional auditing is unable to cater for the values of shariah Islamiah $^{1}[9]$.

Conventional auditing is based on a system which is value-free and does not take into consideration the moral and ethical values laid down by Islam, despite the fact that standard setters believe that the ethical environment is an important factor in improving audit quality [10]. The Western secular model of ethics (reflected in the conventional accounting or auditing) generally propose a system of ethics divorced from religion [11]. Its capitalistic approach is unsuitable for the Islamic economic system, which, on the other hand, places high moral values, fairness and 'Maslahah of the Ummah' (for the benefits of Muslim society) as among its principles. Thus, according to Haneef [12], due to differences in the Islamic economic vision to those of Western economics, coupled with the epistemological and methodological framework in Islamic scholarship, the development of Islamic economic thought (and consequently policy prescriptions) differs. He then suggested that Islamic economics (including finance, banking or accounting) should be evaluated within its own framework and using its own criteria. Therefore, it is important to examine the gap between theoretical and practical aspects of shariah auditing in Malaysian IFIs.

The remainder of the paper has four main sections. First section discusses about the auditing from the perspective of shariah and research questions raised by this study. Next, the research methodology is described. Subsequently, the results are analyzed and presented. Finally, there is a discussion of the findings and a brief conclusion.

\section{Auditing From The Perspective Of Shariah}

Currently, the responsibility of carrying out the shariah audit function is impliedly imposed on the Shariah Supervisory Board (SSB) ${ }^{2}$. Even though the regulators realize the need to have shariah audits for IFIs, there is no mention of the appointment and responsibilities of a shariah auditor per se, nor a specific definition of a shariah audit, in any related Acts or regulations. Section 3 (5) (b) of the Islamic Banking Act (IBA) 1983 does mentioned indirectly on the responsibility of a shariah auditor, but this section is related to the requirement to establish a SSB which includes among others the responsibility of producing and endorsement of a shariah report. The latest Shariah Governance Framework (SGF) issued by the Central Bank discussed on the function of shariah audit as part of the governance structure, hence very limited in scope.

Questions may then arise as to who is responsible to conduct the check and balance (in other words, doing the auditing) on shariah matters which is not covered by the external auditors, particularly in Malaysia. Research conducted by Hood and Bucheery [13] showed that financial (external) auditors were reluctant to undertake the responsibility of ensuring shariah compliance. IBA 1983, BAFIA 1989, BNM/GPS 1, SGF and AAOIFI seem to put the responsibility of forming and expressing an opinion on the extent of an IFI's compliance with shariah (in other words doing the shariah audit e.g. GSIFI 2) on the SSB. In addition, both the AAOIFI standards and the Central Bank's guidelines also give the responsibility of advising, planning and monitoring of the activities of the IFIs (e.g. BNM/GPS 1 and SGF) on the SSB. This however leads to questions of 'independence' which is a fundamental concept in auditing, as auditors cannot audit or examine their own work. Due to the faith-based nature of the business, it is evident that the SSB will reviewed most aspects of the business even though the involvement could vary and focused on approval of basic structure of products and other special activities rather than interfering in the day-to-day operations of business [14].

Furthermore, SSB does not have a mandatory regulated professional code to follow; instead they follow the Islamic shariah principles [15]. Whereas investors of shariah approved companies depend on the SSB's scholarship and expertise in making decisions on evaluating and selecting optimal investment portfolio [16]. Although AAOIFI has come up with the code of ethics for auditors of IFIs, the framework/standards within which to formulate their task as shariah auditors has not so far been defined. The fact that they are guided by their moral beliefs [17] and they are distinguished and knowledgeable shariah scholars [18] makes it difficult to know whether they are competent to perform their duty or not as shariah auditors, even though their position is comparable to the auditors of the IFIs [19]. It is eventually an empirical question as to who is qualified shariah auditing expert, and what are the boundaries of certified knowledge are. Should the auditor be the staff who is within the organization but independent of the areas being audited and reporting directly to management - the classic formulation of the duties of an internal auditor as suggested by Maltby [20] for an environmental auditor.

The current role of the SSB focuses on compliance with rules and procedures and completeness of paperwork. It is easy to show that an IFI can comply with all rules and regulations without adding any value or achieving the objective of the shariah for which its formation is based. The accountability of the shariah audit function carried out by the SSB is thus checked only to the extent of its adherence to rules and procedures. Thus, it may be assumed that the function makes no contribution to assessing the achievement of the objectives

${ }^{1}$ Shariah Islamiah refers to the Islamic Law. 
specifically on the socio-economic objectives. Different from the capitalist environment, in an Islamic society with a very heavy social and ethical agenda, the current practice may be considered inadequate.

On the other hand, the role of the external auditor in an IFI is different and wider than his role in the traditional organizations [21]. This is because it should be extended to cover the compliance with the shariah and auditing in Islam has been derived from the basic values of Islamic society; from traditional concept of "attest and authority" to meeting the socio-economic objectives of the Islamic law [22]. Is the current profession qualified to undertake this extension of duty? By right the auditor auditing IFIs is religiously responsible and his duty is bound to acquire knowledge of shariah and his duty emanates from the principles of Islam and from the general standards of his profession.

Therefore, it is the duty of the auditor to do his best in the capacity of a professional by acquiring related knowledge as the profession requires the auditor to certify that the transactions of the institution which they audit comply with the objective of the institution. Accordingly, if the objective of the IFI is to conduct business in accordance with shariah principles, the auditors of the institution have a responsibility to ensure shariah compliance by virtue of taking the audit assignment. However, as mentioned above, research conducted by Hood and Bucheery [23] showed that external auditors were reluctant to undertake the responsibility of ensuring shariah compliance mainly due to the lack of expertise. Further, Simpson and Willing [24] argued that the role of external auditors in the IFIs was seen to be complex due largely to the lack of experience of most external auditors on the shariah principles. Besar et.al [25] suggested that in ensuring the success of shariah ompliance review framework, IFIs need to promote the involvement of the external auditors in order to enhance the independence and transparency of the industry.

In line with these issues, the present study seeks to examine whether there are sufficient standards for shariah auditing practices for IFIs in Malaysia. Besides that, this study also investigates whether the practitioners of shariah auditing practices in IFIs in Malaysia qualified in both shariah and auditing/accounting related subjects. Finally, this study seeks to observe the issue of independence between the practitioners of shariah auditing practices in IFIs and the organizations they attached.

This research offers several practical and theoretical imperative for regulators, IFIs and the public as a whole. The audit function in an Islamic state is important and mandatory as it reflects the accountability of the auditor not only to the users of the financial statements, but more important, to the Creator, Allah S.W.T. Muslims are believe that one's actions and thoughts are always being watched and it is to be noted that one has the obligation to "account" to God on all matters pertaining to human endeavor for which every Muslim is "accountable" [26].

The prohibition of interest (riba) in Islam and the aspiration of Muslims to make this prohibition a practical reality in their economies, has led to the establishment of a number of Islamic financial institutions around the world [27]. Religious or shariah audit evolved in parallel to the development of Islamic institutions in the Muslim world.

Over the past two decades, the development of Islamic banks has increased immensely and a large number of Islamic banks have been established around the world. As part of the Islamic business institutions, the Islamic banks are obliged to perform Shariah compliance activities in their operations [28]. Starting from the Islamic banking system, the shariah compliance activities later on were applied to other financial sectors such as insurance and capital market. With the drastic development of the Islamic financial system operating in the Islamic and non-Islamic countries, automatically the Islamic accounting and auditing will be important issues under discussion.

In addition to the practical imperative, Muslim scholars and intellectuals are working towards incorporating modern knowledge to give it an Islamic mode which they term as Islamization of knowledge. This is seen as a first step to integrate and develop the Muslim personality and outlook, which had become schizophrenic due to the dichotomization of knowledge between secular and religious, as a result of the modern education received by Muslims ([29], quoted by Shahul [30]).

\section{METHODOLOGY}

The main purpose of this study is to examine the issues of sufficiency standard for shariah auditing practices, qualitifications and independence of shariah auditing practitioners in IFIs in Malaysia. For the purpose of this research, an Islamic financial institution (IFI) is defined with reference to the guideline issued by the Central bank, SGF, as:

a) An Islamic bank licensed under the Islamic Banking Act 1983 (IBA); and

b) A financial institution licensed under the Banking and Financial Institution Act 1989 (BAFIA) which participates in the Islamic Banking Scheme (BAFIA IBS bank).

The empirical data presented in this paper was collected by the way of questionnaire survey setting. 21 Malaysian IFIs are chosen as the focus of this study. A survey of 155 participants who are involved directly and/or indirectly with the process of shariah compliance/auditing from various IFIs in Malaysia was conducted. 
The interested respondents for this study are chosen consistent with Calder [31] that pointed out "when effects application (in this study, the current practices of shariah auditing) is the goal, correspondence procedures require that research participants match individuals in the real world setting of interest".

Out of 155 questionnaires distributed by mail or delivered in person and collected back at a later date, only 88 responded to this survey. Three questionnaires were excluded from the sample due to incompleteness in the majority of the sections. This exclusion leaves a final sample of 85 respondents (response rate of 55\%) in the sample in order to achieve the objectives of this study.

The respondents for this study are consists of 13\% Shariah advisors / committee members (11 respondents), $11 \%$ Shariah auditors / supervisors of the Central Bank (BNM) (9 respondents), 25\% managers / officers of shariah compliance section (21 respondents), $42 \%$ internal auditors (36 respondents), and 9\% external auditors ( 8 respondents) of IFIs in Malaysia. Given that Malaysia has different types of IFIs, out of the 85 respondents, most of them are from Islamic branches of local financial institutions (31\%). This is followed by full-fledged local IFIs (28\%), Islamic window local financial institutions (19\%), full-fledged foreign IFIs $(13 \%)$, and Islamic window foreign financial institutions (9\%).

The self-developed instruments inclusive of 77 information items were used in this research survey. The respondents were instructed to indicate the relative importance of each item of information on a five-point likert scale. The point values are as follows: 1 - strongly disagree; 2 - disagree; 3 - neutral; 4 - agree; and 5 strongly agree. The survey instrument was accompanied by instructions on how to complete the survey and then return it to the principal researcher in a reply-paid envelope.

The findings of the research are achieved through the analysis of the responded surveys using the relevant parametric and non-parametric statistical tests. Some of the parametric tests are $t$-test, Pearson correlation, one-way analysis of variance (ANOVA); while non-parametric tests are Mann-Whitney U test, Wilcoxon signed-ranked test, Spearman correlation and Kruskal-Wallis analysis of variance by ranks test.

\section{FINDINGS AND Discussions}

The following commentary presents the findings based on the three key issues that were identified from the literature and research questions. The three issues are regards to the sufficiency standard for shariah auditing practices for IFIs in Malaysia; qualifications of shariah auditing practitioners; and independence of shariah auditing practitioners in IFIs in Malaysia.

\subsection{Issue on Sufficiency Standard for Shariah Auditing Practices}

The analysis commenced by examining the issue of whether there are sufficient standards for shariah auditing practices for IFIs in Malaysia. Table 1 indicates the four information items which was considered important information for the issue of sufficiency standard for shariah auditing practices for Malaysian IFIs.

The overall aggregate mean score is 3.05 and median is 3.00 (refer to Table 1). Item 45 depicts the lowest overall mean of 2.69 while the highest is item 46 with overall mean of 3.42. The results indicate that the local standards are being used by the Shariah auditing practitioners in Malaysia IFIs. This empirical evidence is not accommodating as local standards are found to be an imitation to the international conventional auditing standards and may not be suitable to the IFIs, but they have not much choice but to follow the regulations. Therefore the respondents then have to rely on the AAOIFI standards (item 45), and even making the standards superior than the local standards (item 48). This finding shows that there is a need for an integrated shariah auditing standards that covers all aspect of shariah compliance ought to be implemented. This to ensure that shariah audit practitioners are able to perform an audit practices in the manner of Islamic compliance.

Table 1: Responses on Sufficiency Standards of Shariah Auditing

\begin{tabular}{|c|c|c|c|c|c|c|c|}
\hline \multirow[t]{2}{*}{ Items } & \multirow[t]{2}{*}{ Statements } & \multicolumn{2}{|c|}{$\begin{array}{l}\text { Full-Fledged } \\
\text { IFIs }\end{array}$} & \multicolumn{2}{|c|}{ Others } & \multicolumn{2}{|c|}{ Overall } \\
\hline & & Mean & Median & Mean & Median & Mean & Median \\
\hline III:45 & $\begin{array}{l}\text { AAOIFI standards are being } \\
\text { used for shariah auditing in } \\
\text { this organization } \\
(\mathrm{N}=59) \text {-reserve-coded }\end{array}$ & 2.80 & 3.00 & 2.62 & 3.00 & 2.69 & 3.00 \\
\hline III:46 & $\begin{array}{l}\text { Local auditing standards are } \\
\text { being used instead of } \\
\text { AAOIFI's } \\
(\mathrm{N}=59)\end{array}$ & 3.51 & 4.00 & 3.36 & 3.00 & 3.42 & 4.00 \\
\hline III:47 & $\begin{array}{l}\text { The existing standards are } \\
\text { sufficient for shariah } \\
\text { auditing in IFIs }\end{array}$ & 3.37 & 4.00 & 3.22 & 3.00 & 3.28 & 3.00 \\
\hline
\end{tabular}


Emerging issues for shariah auditing in Islamic financial institutions: Empirical evidence from

\begin{tabular}{|l|l|l|l|l|l|l|l|}
\hline & $(\mathrm{N}=59)$-reverse-coded & & & & & & \\
\hline III:48 & $\begin{array}{l}\text { In the case of conflicts, } \\
\text { AAOIFI standards supersede } \\
\text { local auditing standards } \\
(\mathrm{N}=57) \text {-reverse-coded }\end{array}$ & 2.97 & 3.00 & 2.70 & 3.00 & 2.81 & 3.00 \\
\hline Aggregate Means & 3.16 & 2.98 & $\mathbf{3 . 0 5}$ \\
\hline Aggregate Median & 3.25 & 3.00 & $\mathbf{3 . 0 0}$ \\
\hline Normality Test & $.000^{*}$ & \multicolumn{2}{|l|}{} \\
\hline
\end{tabular}

Note: * Coefficient is significant at $5 \%$ level

Since the implementation of AAOIFI is not mandatory in Malaysia, the finding shows that all the existing standards are not sufficient in the practice of shariah auditing in IFIs in Malaysia (item 47). In view of the normal distribution assumption is violated ( $\mathrm{p}$ value $<.005$ ), both the $t$-test and sign test are employed in order to determine the significance of median. The median is used as it provides more meaningful measures for ordinal scale of data.

Table 2: Parametric and Non-Parametric Tests Results on Sufficiency Standards of Shariah Auditing

\begin{tabular}{|l|l|l|l|l|l|l|}
\hline \multirow{2}{*}{} & \multirow{2}{*}{$\mathbf{N}$} & \multicolumn{2}{|l|}{ Parametric Test } & \multicolumn{2}{l|}{ Non-Parametric Test } \\
\cline { 3 - 7 } & & & \multicolumn{2}{l|}{ One-Sample t-test } & \multicolumn{2}{l|}{ Signed Rank Test } \\
\cline { 3 - 7 } & Mean & $\boldsymbol{t}$-statistic & $\boldsymbol{p}$ value & Median & Sig. value \\
\hline $\begin{array}{l}\text { Sufficiency Standards } \\
\text { of Shariah Auditing }\end{array}$ & 58 & 3.0579 & .894 & .187 & 3.00 & .275 \\
\hline
\end{tabular}

Table 2 shows the results of the $t$-test for mean value and sign rank test for median at above 3.50. Results reported that there is no significant difference of mean/median at above 3.50 because, even at 3.00, the results record insignificant $\mathrm{p}$-values at .05 . Therefore, both mean and median are insignificant at above 3.50 , implying that there are insufficient standards for the shariah auditing practices in Malaysian IFIs.

\subsection{Issue on Qualification of Shariah Auditing Practitioners}

Practitioners of shariah auditing practices are expected to serve the needs of the Islamic society whose focus and priorities are different from other worldviews. As any other organizations, shariah auditing practitioners of IFIs seem to be held accountable not only for the manner in which appropriated funds are utilized, also for the transparency of the financial account. It is expected that the practitioners of shariah auditing practices in Malaysian IFIs are qualified in both shariah and accounting/auditing related subjects. The shariah auditors should be the one with adequate knowledge, capabilities and independent to carry out the audit.They must have been trained in accounting and finance and auditing as well as shariah and fiqh [32].

Empirical findings shows that the proportion of those respondents who qualified in both shariah and accounting/auditing qualifications is on $5.90 \%$ as compared to those respondents who practice shariah auditing in IFIs in Malaysia (69\%). Respondents whose have both qualifications is internal auditors and the management of shariah division. No doubt that there are those who are qualified in either one of the two qualifications to be working in a team, but the fact that a very low percentage of those practitioners with both qualifications may slow down an integrated of shariah auditing process to take place in the IFIs.

Correlation analysis conducted shows that there is a significant negative weak correlation between those respondents with accounting and shariah qualifications ( $r$ value $=-.303, p$-value $<.05)$. This indicates that those with accounting qualifications often tend not to have shariah qualifications at the same time. Further significance test of proportion revealed the consistent results with the correlation analysis. According to Table 3 , the evidence is clear that there is a significant different between practitioners of shariah auditing in Malaysian IFIs who possess both shariah and accounting qualifications with those who do not.

Table 3: Significant Tests Results of Proportion for Qualifications

\begin{tabular}{|c|c|c|c|}
\hline \multirow{2}{*}{ Qualifications } & \multirow{2}{*}{$\mathbf{N}$} & \multicolumn{2}{|c|}{ Independent Sample $t$-test } \\
\hline & & t-statistic & $p$ value \\
\hline - Have Both Qualifications & 5 & \multirow{2}{*}{0.500} & \multirow{2}{*}{$.000 * * *$} \\
\hline - Do Not Have Both Qualifications & 54 & & \\
\hline
\end{tabular}

Note: $* * *$ Coefficient is significant at $1 \%$ level 
Lack of shariah auditing practitioners with both qualifications indirectly may distort the growth of shariah auditing. This subsequently may fail in determining the vision and mission of Islam that preserved within the IFIs. This result is consistent with Kasim et al. [33], as they mentioned that there is still lack of people who have both shariah and accounting qualifications. Yaacob [34] agreed that the lack of both shariah and accounting knowledge has dampened the crucial needs of the shariah auditor. According to $\mathrm{PwC}$ [35], the shariah audit function is to be performed by internal auditors who have adequate shariah related knowledge and skills. Their ultimate goal is to ensure a sound and effective internal control system for shariah compliance. Internal auditor may also engage the expertise of IFIs shariah officers in performing that audit so long as the objectivity of the audit is not compromised. However, IFIs may also appoint an external party to conduct a shariah audit on their banking operations.

\subsection{Issue on Independence of Shariah Auditing Practitioners}

The final issue to observe is the issue of independence between the practitioners of shariah auditing practices in IFIs and the organizations they attached. The auditors must ensure that they uphold the integrity in performing their tasks. The integrity of the shariah auditor needs to be perceived as independent enough by those stakeholders of IFIs. Previously, Haniffa [36] raised a question of the SSB independence as they are making fatwas and at the same time helping the shariah auditors in conducting shariah review or shariah audit. Clearly there is no clear line on the separation of duties which is essentials for any good internal control practices. The IFIs need to rethink of where they could clearly separate these roles to avoid the misperception of the stakeholders on the SSB and/or shariah auditors' independence.

As discussed in the literature, an independent auditor must be free from restrictions or bias if he is to be totally independent [37]. In Malaysian IFIs, the internal auditors and personnel at the management of shariah section are among the highest percentage that practice shariah auditing. As they are full-time employees of the IFIs, this implies that the perceived independence has been violated. Results in Table 4 further confirm that the ratio of those who practice shariah auditing than those who not practicing are more than $50 \%$ as reflected by the significant $p$ value.

Table 4: Significant Tests Results of Proportion for Independence

\begin{tabular}{|l|l|l|l|}
\hline \multirow{2}{*}{ Qualifications } & \multirow{2}{*}{$\mathbf{N}$} & \multicolumn{3}{|l|}{ Independent Sample $\boldsymbol{t}$-test } \\
\cline { 5 - 5 } & & t-statistic & $\boldsymbol{p}$ value \\
\hline • Practice Shariah Auditing & 48 & \multirow{2}{*}{0.500} & $.000 * * *$ \\
\hline • Do Not Practice Shariah Auditing & 11 & & \\
\hline
\end{tabular}

Note: $* * *$ Coefficient is significant at $1 \%$ level

In situations where the absolute independence is impossible, shariah auditors must strive to maintain a high level of independence in fact and in appearance. For example, the internal shariah auditors of IFIs may report directly to the top management, keeping them independent of the department that they audit.

\section{IMPLICATIONS AND CONCLUSION}

Generally, there are still few unresolved issues in shariah audit in terms of standard for shariah auditing practices, shariah auditor's qualification and their independence. If these remain unresolved, specifically in terms of lacking in a properly guided and comprehensive framework of shariah auditng and shortage of expertise, the smooth development of the Islamic banking and finance industry will be distorted. They should be resolved immediately as this may have an impact on the confidence of the stakeholders on the validity of the shariah compliance of the Islamic financial institution's products and service on its operations and activities. This study also argues that shariah audit, as a social function, is a very important assurance tool to achieve the maqasid as shari'ah (objectives of the Islamic law).

As far as Malaysia is concerned, it can be concluded that the practice of shariah auditing is still considered to be an insignificant agenda for IFIs in Malaysia despite the fact that Malaysia is in the process of becoming a one-stop center for Islamic banking and finance. In fact, the standards and guidelines used to cater for shariah auditing are still under developed with only a small portion of it is included in the latest shariah governance framework issued by the Central Bank of Malaysia. In the absence of generally accepted criteria of shariah auditing, this research finds that people who are directly or indirectly involved with shariah auditing in IFIs in Malaysia consider shariah auditing function is evolving and having a proper framework of shariah auditing would be part of their main agenda in future undertaking. It has a significant impact on their current shariah audit practice. It is reasonable to infer, therefore, that in addition to having a framework of shariah auditing in IFIs in Malaysia, shariah auditors also consider the framework to be different and distinct from the normal conventional auditing framework. 
One important policy implication of this study is that the Malaysian Institute of Accountants (MIA) or the regulatory body in charge of IFIs, should be assigned to take the responsibility of identifying and implementing a comprehensive and integrated shariah auditing framework in order to cater for the ever increasing number of IFIs in Malaysia. Hence, the agenda of having a properly guided shariah compliance assurance process in the form of implementing a shariah audit framework for IFIs needs to be in the list of priorities for the development of the industry as a whole.

There is also evidence to suggest that shariah auditors are likely to be a different group of auditors with specialized qualifications both in shariah and accounting areas of study. In fact, one policy inference from this study is that it would be beneficial for a CPA firm who audits IFIs to establish specific policies to ensure that its partner(s) and audit staffs who are involved in shariah auditing are qualified in shariah on top of the technical accounting qualifications they have. In consequence, university accounting departments may find it rewarding to include shariah auditing courses in their syllabus or producing graduates with double majors in accounting and shariah. A related policy implication to this is for the profession and the CPA firms to encourage closer interaction between the practitioners and accounting academics for field research and funding the research.

Another policy implication of this research comes from the result of the study on the issue of independence among the practitioners of shariah auditing. The implication is that if shariah auditors are to be perceived as independent, then the shariah audit should be carried out by the external auditors. Likewise, if the regulations allow IFIs to make use of the internal units, then they should accommodate the audit staff to report directly to the Audit Committees or Board of Directors to mitigate the 'self-review' threat.

\section{Acknowledgements}

This paper acknowledge the Malaysian Higher Education for sponsoring the project through its research center, ARIHICoE and the Research Management Institute, UiTM for the management of the funding.

\section{ENDNOTES}

${ }^{1}$ Essentially adopts the Western philosophical approach to Islamic accounting theory and practice which do not at least on the surface, contradict legal rules of Islamic law (fiqh).

${ }^{2}$ SSB is also known as ShC (Shariah Committee) members, SA (shariah advisors) and some other names depending on the IFIs. For the purpose of this research, ShC, SSB or SA is used interchangeably.

\section{REFERENCES}

[1] Barlaup, K., Dronen, H. I. and Stuart, I., Restoring trust in auditing: Ethical discernment and the Adelphia scandal, Managerial Auditing Journal, 24(2), 2009, 183-203.

[2] Humphrey, C., Debating audit expectations: Current issues in auditing, (Paul Chapman Publishing Ltd., London, 2000).

[3] Houck, T. P., Why and how audits must change, (John Wiley \& Sons, Inc., Canada, 2003).

[4] Ball, R., Kothari, S. and Robin, A., The effect of international institutional factors on properties of accounting earnings, Paper presented at International Accounting Research Conference, 1998, Chicago.

[5] Blair, I., The audit expectation gap widens as the failures grow, Company Director, June, 1990, 39.

[6] Banaga, A., Ray, G. and Tomkins, C., External audit and corporate governance in Islamic banks: A joint practitioner-academia research study, (Avebury, Hants, England, 1994)

[7] Shahul, H. M. I., The need for Islamic accounting: Perceptions of its objectives and characteristics by Malaysian accountants and accounting academics, Unpublished PhD thesis, University of Dundee, United Kingdom, 2000.

[8] Gary, P., Nonna, M. \& Liang, C., The impact of codes of ethics and experience on auditor judgments, Managerial Auditing Journal, 22(6), 2007, 566-589.

[9] Harahap, S. S., Auditing dalam perspektif Islam [Auditing in the Islamic perspective], (Pustaka Quantum, Jakarta, 2002).

[10] Gary, P., Nonna, M. \& Liang, C., The impact of codes of ethics and experience on auditor judgments, Managerial Auditing Journal, 22(6), 2007, 566-589.

[11] Beekun, R. I., Islamic Business Ethics, (Herndon, Virginia: The International Institute of Islamic Thought, 1997).

[12] Haneef, M. A. M., Islam, the Islamic worldview and Islamic economics, IIUM Journal of Economics and Management, 5(1), 1997, $39-65$.

[13] Hood, K. L. and Bucheery, R., The interaction of financial and religious (Islamic) auditors with reference to the audit expectation gap in Bahrain, Accounting, Commerce and Finance: The Islamic Perspective Journal, 3(1 \& 2), 1999, 25-58.

[14] Besar, M.H.A., Sukor, M.E., Abdul Muthalib, N. and Gunawa, A.Y., The practice of shariah review as undertaken by Islamic banking sector in Malaysia, paper presented at International Review of Business Research Papers Conference II, 2009, Kuala Lumpur, Malaysia.

[15] Banaga, A., Ray, G. and Tomkins, C., External audit and corporate governance in Islamic banks: A joint practitioner-academia research study, (Avebury, Hants, England, 1994).

[16] Mohd Dali, N.R., Mudasir, H.H. \& Abdul, H.S., Performance of Shariah compliance companies in the plantation industry, International Journal of Islamic and Middle Eastern Finance and Management, 1(2), 2008, 166-178.

[17] Karim, R. A. A., The independence of religious and external auditors: The case of Islamic banks, Journal of Accounting, Auditing and Accountability, 3(3), 1990, 34-43.

[18] Abdul Rahim, A. R., Abu Bakar, N. B. and Syafie, A. W., A preliminary study on the responsibility and independence of shariah advisors of Islamic banks, Proceedings of IIUM Accounting Conference II, 2004, Kuala Lumpur, Malaysia.

[19] Besar, M.H.A., Sukor, M.E., Abdul Muthalib, N. and Gunawa, A.Y., The practice of shariah review as undertaken by Islamic banking sector in Malaysia, paper presented at International Review of Business Research Papers Conference II, 2009, Kuala Lumpur, Malaysia. 
[20] Maltby, J., Environmental audit: theory and practices, Managerial Auditing Journal, 10(8), 1995, 15-26.

[21] Banaga, A., Ray, G. and Tomkins, C., External audit and corporate governance in Islamic banks: A joint practitioner-academia research study, (Avebury, Hants, England, 1994).

[22] Khan, M. A., Role of supreme audit institutions in shaping the Islamic economy in the 21st century, IIUM Journal of Economics and Management, 9(1), 2001, 77-100.

[23] Hood, K. L. and Bucheery, R., The interaction of financial and religious (Islamic) auditors with reference to the audit expectation gap in Bahrain, Accounting, Commerce and Finance: The Islamic Perspective Journal, 3(1 \& 2), 1999, 25-58.

[24] Simpson, A. and Willing, P. Accounting and auditing issues in Islamic banking, in Asma Siddiqi (ed.), Antology of Islamic Banking. (London: Institute of Islamic Banking and Insurance, 2000).

[25] Besar, M.H.A., Sukor, M.E., Abdul Muthalib, N. and Gunawa, A.Y., The practice of shariah review as undertaken by Islamic banking sector in Malaysia, paper presented at International Review of Business Research Papers Conference II, 2009, Kuala Lumpur, Malaysia.

[26] Askary and Clark, Accounting in the Quranic Verses, Accounting, Commerce and Finance: The Islamic Perspective Journal, 1997, 139-152.

[27] Chapra, M.U. and Khan, T., Regulation and supervision of Islamic banks, (Islamic Development Bank (IRTI), Jeddah, 2000).

[28] Abdul Rahim, A. R., Abu Bakar, N. B. and Syafie, A. W., A preliminary study on the responsibility and independence of shariah advisors of Islamic banks, Proceedings of IIUM Accounting Conference II, 2004, Kuala Lumpur, Malaysia.

[29] Brohi, A. K., Islamization of knowledge: A first step to integrate and develop the Muslim personality and outlook in ISLAM, (Source and Purpose of Knowledge, Herndon, Virginia: International Institute of Islamic Thought, 1988).

[30] Shahul, H. M. I., The need for Islamic accounting: Perceptions of its objectives and characteristics by Malaysian accountants and accounting academics, Unpublished PhD thesis, University of Dundee, United Kingdom, 2000.

[31] Calder, B. J., Phillips, L. W. and Tybout, A. M., Designing research for application, Journal of Consumer Research, September, 1981, 197-207.

[32] Yaacob, H. and Donglah, N. K., Shari'ah audit in Islamic financial institutions: The postgraduates' perspective, International Journal of Economic and Finance, 4(12), 2012, 224-239.

[33] Kasim, N., Mohamad Ibrahim, S. H. and Sulaiman, M., Shariah auditing in Islamic financial institutions: Exploring the gap between the "desired" and the "actual", Global Economy and Finance Journal, 2(2), 2009, 127-137.

[34] Yaacob, H. and Donglah, N. K., Shari'ah audit in Islamic financial institutions: The postgraduates' perspective, International Journal of Economic and Finance, 4(12), 2012, 224-239.

[35] Price Waterhouse Coopers, Shari'ah audit: industry insight. http://www.pwc.com/en MY/my/assets/publications/Shariah-Audit.pdf

[36] Haniffa, R., Auditing Islamic financial institutions. Islamic finance: instrument and market, (Qfinance, 2010), 109-112.

[37] Haron, H. et.al, The reliance of external auditors on internal auditors, Managerial Auditing Journal, 19(9), 2004, 1148-1159. 